\title{
Strategic Performance Management System and Corporate Sustainability Concept - Specific Parametres in Slovak Enterprises
}

\author{
- Rajnoha Rastislav, Lesníková Petra
}

\begin{abstract}
Nowadays, a well-performing enterprise can be considered the one that is able to use many opportunities, to adapt to continual changes in the environment, to achieve better performance. Business performance is often seen as an indicator of the enterprise's results and effects. In the area of business performance and strategic performance measurement system, many studies have been realized which identify the major factors affecting the performance of the company itself. The paper is focused on the analysis and identification of specific factors in the form of localization, turnover of enterprise and others which may have a potential impact on performance. Current trends are focused not only on the performance, but also the consequences of corporate activities of environment. This leads to better competitiveness of companies. In this context, attention is drawn to the orientation of enterprises on particular dimensions of corporate sustainability concept and factors such as company size or capital structure in relation to its application.
\end{abstract}

Keywords: business performance, strategic performance measurement system, specific factors, corporate sustainability concept

JEL Classification: M14, M21, Q56

\section{INTRODUCTION}

The increasing number of conducted researches relating to business performance only emphasizes the importance of this issue. Performance management can be specified as a way of managing and motivating employees based on targets defined mainly of quantitative performance indicators (Hudymáčová \& Hila). A number of foreign authors and their research results bring much knowledge in a field of business performance. Many of them are devoted mutually to the cohesion of business performance with parameters such as corporate strategy, strategic decision making tools to support performance in the form of the Balanced Scorecard (BSC), system of key performance indicators (KPI), information support by Business Intelligence (Bisbe \& Malagueño 2012; Gimbert, Bisbe \& Mendoza, 2010; Chenhall 2005; Rajnoha et al. 2013; Rajnoha, Štefko Merková \& Dobrovič, 2016). In addition to the above mentioned factors, business performance can affect other specific parameters such as the impact of the company location, its size, capital structure, legal status, size or turnover. From the point of view of the complexity, we consider the knowledge of all parameters affecting performance important.

A preferred focus on achieving higher business performance does not necessarily mean that the enterprise cannot be oriented to the corporate sustainability concept. This concept requires 
that enterprises respect and observe the principles of sustainable development (Financial Times Lexicon), which means that the responsibility of a business is much broader than just being linked to the economic aspects of products and services that customers want, hence the profits. The concept of triple bottom line (TBL) and on this issue based the corporate sustainability concept add to the social (towards the community) and environmental (use of resources and reduce disposal) indicators of measuring business performance (Hubbard, 2009). An important issue is prioritization of the corporate sustainability concept and its understanding. In connection with the concept, we are interested in specific parameters such as the impact of the company size and capital structure on the corporate sustainability application.

\section{LITERATURE REVIEW}

\subsection{Characteristics of performance measurement system}

Success and its achievement affects management decision-making with regard to further strategic development. This decision also depends on the adequate assessment of business performance, confirming the importance of choosing a set of indicators - financial and non-financial as well as their evaluation.

Performance measurement system, as stated by Nelly et al. (2003), relates to the use of multidimensional set of indicators (financial, non-financial, internal, and external). The role of performance measurement system as a subsystem is identified as part of the strategic performance management, whereby the performance management system is responsible for the implementation process. Strategic performance measurement system (SPMS) allows enterprise to plan, measure and monitor its performance, such that making decisions, resources and activities can be better aligned with the business strategies to achieve the desired results and creating value for shareholders (Bento, Bento \& White, 2014). Other study indicates that there is a positive significant relationship between management tools and techniques utilization and organizational performance (Afonina, 2015). Other research in Germany interprets that due to some significant correlations between innovations and financial and quality performance, it is not possible to provide a clear statement about the impact of innovations on the performance (Heurich \& Vignali, 2015). The research in Romania, where sample consisted of 73 multinational companies, investigated a linkage between corporate social performance and financial performance. The authors, according to statistical analysis results state that improving CSR does not necessarily lead to better financial performance (Miron \& Petrache, 2012). Strategic management system should be able to follow and 'control' the process of implementation (de Lima et al., 2009).

In terms of tools to support, the SPMS is a typical representative of the BSC methodology which covers three key functions in the enterprise: the measurement, the strategic management system and tool for communication (Striteska \& Spickova, 2012). The primary essence of BSC is that success is achieved through a combination of financial and non-financial key indicators. The implementation of methodology can help managers to identify those key non-financial indicators that are linked to the achievement of certain financial indicators (Davis \& Albright, 2004). BSC have vindicated more and more enterprises, and on the basis of research, it is evident that BSC positively contribute to the operational performance of enterprises (De Geuser, Mooraj \& Oyon, 2009). 
In relation to BSC, the Tableaux de Bord is less used tool for decision support and business management. It enables the company to achieve its overall objectives and successfully implement the business strategies. This tool is based on models of the trading system / area of responsibility. Its aim is to reduce complexity and focus attention of managers on the parameters and key areas that are relevant to the decision, the individual managers to ensure complex information in the form of indicators that need for (operational) control (Daum, 2005).

The development and the rate of use of tools to support business performance over the years has changed. From using only financial indicators, the promotion of indicators of non-financial areas, through their mutual combination to the implementation and use of information technology to support performance improvement. Based on comprehensive research of the business performance, it is clear that the above mentioned BSC methodology is an integral part of the SPMS. It is necessary to support BSC through knowledge information system BI, leading to achieve a higher business performance (Rajnoha, Štefko Merková, \& Dobrovič, 2016). The consulting firm Bain \& Company annually carries out extensive research concerning the use of management tools. Each survey highlights regional differences in the use of tools as well as satisfaction with their usage. According to survey carried out in 2015, we can see the difference between regions, preferring traditional tools and those that focus on newer tools linked to the trend of digital transformation. Such differences may be based primarily on various perspectives of key trends - growth, innovation, cost and complexity, investment in e-transformation and a better understanding of customers (Rigby \& Bilodeau, 2015). Some examples are presented in Table 1.

Tab. 1 - The utilization rate of selected management tools in enterprises by region in 2015 .

Source: Rigby \& Bilodeau, 2015

\begin{tabular}{|l|c|c|c|c|}
\hline Management tool & $\begin{array}{c}\text { North } \\
\text { America }\end{array}$ & $\begin{array}{c}\text { Europe Middle } \\
\text { East }\end{array}$ & $\begin{array}{c}\text { Asia } \\
\text { Pacific }\end{array}$ & $\begin{array}{c}\text { Latin } \\
\text { America }\end{array}$ \\
\hline $\begin{array}{l}\text { Customer Relationship } \\
\text { Management }\end{array}$ & $48 \%$ & $50 \%$ & $48 \%$ & $38 \%$ \\
\hline Benchmarking & $50 \%$ & $50 \%$ & $29 \%$ & $42 \%$ \\
\hline Strategic Planning & $50 \%$ & $31 \%$ & $42 \%$ & $52 \%$ \\
\hline Balanced Scorecard & $39 \%$ & $44 \%$ & $28 \%$ & $39 \%$ \\
\hline Change Management Programs & $37 \%$ & $39 \%$ & $24 \%$ & $31 \%$ \\
\hline Big Data Analytics & $27 \%$ & $24 \%$ & $52 \%$ & $17 \%$ \\
\hline Total Quality Management & $22 \%$ & $25 \%$ & $47 \%$ & $28 \%$ \\
\hline Business Process Reengineering & $22 \%$ & $21 \%$ & $32 \%$ & $35 \%$ \\
\hline $\begin{array}{l}\text { Organizational Time } \\
\text { Management }\end{array}$ & $22 \%$ & $17 \%$ & $31 \%$ & $14 \%$ \\
\hline Digital Transformation & $14 \%$ & $14 \%$ & $33 \%$ & $15 \%$ \\
\hline
\end{tabular}

From the table above, it is clear that the preferences and satisfaction with management tools is significantly different from region to region. The data highlight clear split between North American companies, strongly preferring traditional tools, Chinese and Indian companies, which re- 
corded greater use of tools of a new phase as a Disruptive Innovation Labs (Rigby \& Biladeau, 2015). The study points out that understanding the differences between regions and countries can produce interesting results, based on survey in the regions where enterprises with higher performance are concentrated.

Performance measurement is currently also used to assess the impact of corporate activities on all parties interested. That measurement can be considered 'to quantify the efficiency and effectiveness of operations', which makes the actual reporting of the enterprise. In the case of measuring the impact of performance on customer satisfaction, it is not as obvious as in the case of measuring the impact of activities and performance on satisfaction of employees and local communities (Bourne et al., 2003).

\subsection{Corporate sustainability as a business concept}

The corporate sustainability concept has evolved from a globally oriented concept of sustainable development, especially the popular term from the Report of the Brundtland Commission. It consists of an acceptance of three pillars: economic, social, environmental. In the case that an enterprise incorporates sustainable development, it is called a corporate sustainability (Baumgartner \& Ebner, 2010). From a microeconomic point of view, in the research terminology there is used multiple terms. Some examples: sustainable development of enterprises, corporate sustainability, sustainable enterprise, the sustainability promoting firm, and so on. In connection with this fact, it is necessary to distinguish, as the Hyršlová (2009), the 'sustainable' companies and companies which adopt the concept of sustainable development and try to make business activities consistent with the concept. In such a meaning, there are required changes in all business processes, objectives and target values.

In general, the sustainability can be understood in terms of efforts to maintain, respectively maintain the status quo. The different understanding of sustainability implies achieving balanced economic, environmental and social factors in the course of further development. From the view of J. Zelený (2007, p. 257), the concept represents 'the strategy and practices ensuring the current requirements of stakeholders so that they satisfy it in accordance with the principles of sustainable development, so that existing activities allow to meet the needs of future generations, especially from the view of sufficiency, range of natural resources, development and environmental protection'. It touches particularly the businesses and industry because just these fields play an important role in the context of implementation of the rules and principles of sustainable development.

M. Wilson (2003) states that the concept is a mix of several concepts, including sustainable development, corporate social responsibility and stakeholder theory (see Fig. 1). Sustainable development means a broad social goal for all stakeholders and it promotes areas that it is necessary to focused on (environmental, social and economic performance). The arguments why enterprises should pay attention to these areas appear from social responsibility and stakeholder theory. If society as a whole believes in sustainable development as a useful target, enterprises have an ethical obligation to help achieve it. 


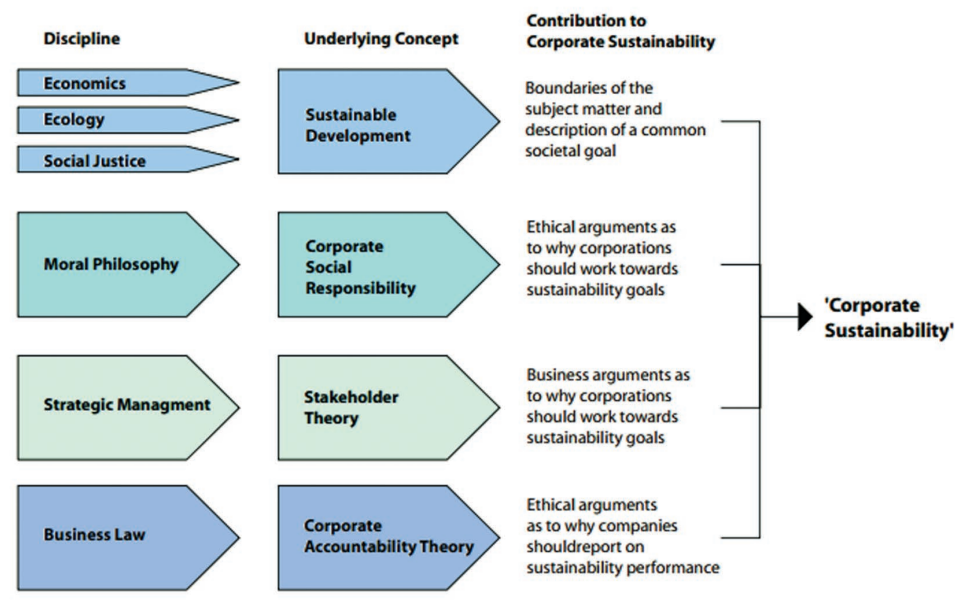

Fig. 1 - Evolution of corporate sustainability. Source: Wilson, 2003

The enforcement of sustainable development concept at enterprise level can be motivating for several reasons (Hyršlová, 2009, pp. 10-11): tends to increase economic and environmental efficiency of technological processes; a mitigates the negative impacts on health, environment and property; the relation of business and sustainable development can be "marketing" element that can improve economic results; the prevention of potential problems when dealing with state authorities, local government and other leaders of society; the acceptation of principle increases the positive attitude of employees to the company, making it possible to achieve significant economic effects; the increase of attractiveness for potential investors and international cooperation.

Porrit (University of Cambridge Programme for Industry, 2003) notes that not all potential presented motives, respectively benefits are linked to each establishment. It depends primarily on the sector in which the company operates, as well as at the level of direct contact with the consumer, by legislative pressures and so on. Shirastava and Hart (1995) as the main reason consider in particular the fact that corporate sustainability is increasingly becoming a competitive advantage, where people and businesses are evaluated in the sense that they have a moral responsibility to minimize own impact on the planet.

Enterprises are inherently more and more focused on short-term economic performance, as a long-term vision of environmental and social sustainability. This is apparent primarily from the anthropocentric character and values, creating a shortage of a holistic view of the business (Setthasakko, 2007; Ionescu-Somers, 2012). Grayson et al. (2008) consider for a major barrier of concept implementation based on TBL ambiguity of the concept in terms of changes for the better. Problem areas can be seen in the negligence on the part of management, the involvement of stakeholders, and in integrating sustainability into business objectives and strategies.

As the external environment changes, these changes need to be integrated in business management. Among the most basic environmental factors that managers have experienced in recent years is the impact of products and services to the world community and environment. In this 
way the element of corporate sustainability is integrated to the field of strategic management. These procedures are the summary of sustainable strategic management (Stead \& Stead, 2012). Sustainable strategic management, on the one hand, creates a linkage between social, environmental aspects and strategy of the company; on the other hand, it integrates social and environmental information to knowledge management. This means that the company and its strategic management makes it sustainable if the business reflects the relationship to social and environmental mission, values and vision, taking into account social and environmental impacts, has provided performance measurement and so on (Fülöp \& Hernádi, 2014). Top management must set the values and vision of sustainable development and ensure that they are not only integrated into corporate strategies, policies and corporate culture, but also communicated to all employees. Businesses that not only identify and transmit core values, but also clearly define priorities of economic, environmental and social nature, it can reach a competitive gap just by proactive management of the organization's performance (Knirsch \& Székely, 2005).

\section{METHODOLOGY}

The objective of this paper is to analyze specific parameters that can potentially have an effect on the performance. As the specific parameters, we consider the business location, turnover, legal form and etc. Current trends point to the need that company should be mentioned not only as a separate entity but also as a part of the wider world, representing all stakeholders to extend responsibility of the company not only from the economic perspective. In connection with the corporate sustainability concept, we focused on the enterprises orientation on particular dimensions as well as parameters such as company size, capital structure in respect of its application. The paper is a synthesis of researches conducted on a sample of businesses operating in the Slovak Republic in the areas of business performance and corporate sustainability.

\subsection{Material and methods used in the analysis of business performance}

For the purposes of the currently presented research and in order to achieve the objectives set, we have decided to obtain the necessary data and information on the enterprises in Slovakia with help of an extensive online questionnaire. We have asked 1.457 chosen businesses to participate in the survey, representing selected industry segments in Slovakia.

The particular data about the primary database of 1.457 enterprises from selected industries of the Slovak Republic were received from information of various industrial associations. This database was subsequently supplemented by other companies on the base of extensive online survey. After these two consecutive rounds the questionnaires were correctly completed by 164 enterprises in the end. We consider the size of the research sample - 164 enterprises as being sufficiently representative and this is $11.26 \%$ share of the total number of companies surveyed.

The greatest extent was represented by businesses of engineering, wood and automotive industries. In order to identify and analyze the parameters for measuring and managing business performance, a key issue was the size of ROE. Based on this, we have incorporated enterprises in various performance categories with six scaled intervals. The differentiation of enterprises into the performance groups is shown in Figure 2. 


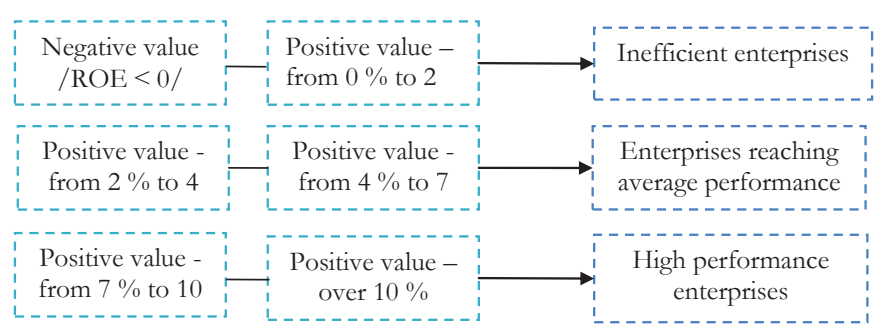

Fig. 2 - The enterprise differentiation into the performance groups. Source: own

The results obtained by questionnaire survey were processed by statistical methods. Selected variables were processed by descriptive statistics. For one variable (frequency, relative proportions) we have used mainly Chi-square test of independence. It is used to test the categorical variable weather there is a relationship between these variables or not. In analyzing this relationship, we started from Pivot Tables and Pivot coefficients. For the analysis of the difference between observed (empirical) and expected (theoretical) frequency, we used the Pearson chi-square test. Besides this, we also used a similar M-V chi-square test, which is based on the theory of maximum likelihood that is used in the case that there is a real dependence between variables. If the value corresponds to the chi-square probability $\mathrm{p}>0.05$, this means that the relationship between variables is not statistically significant, and vice versa, if $\mathrm{p} \leq 0.05$, it is possible strong relationship between two variables tested using one of the contingency factors. The Phi coefficient determines the degree of correlation between two categorical variables for $2 \times 2$ tables. Its value ranges from -1 to 1 (total dependence) or 0 (variables are not correlated with each other). The hypothesis was verified at 5\% significance level $(\alpha=0.05)$. All data about enterprises were processed using MS Excel software Statistica and Statistica 10 CZ 10 Data Mining and Statistic program SPSS.

In the analysis, we focused on specific parameters and we have formulated the following hypotheses:

H1: We assume that the business performance was affected their location, which will be categorized by the region SR.

H2: We assume that enterprises which increase their turnover will achieve it proportionally to higher performance.

H3: We assume that the corporate legal form will also affect the performance, especially the limited liability companies and joint stock companies will achieve higher performance.

H4: We assume that the size of enterprises, linked to the number of employees, will affect the performance only to a certain extent, so we assume that the high-performance enterprises will be medium-sized enterprises with 50-250 employees, which they are able to flexible adaption to changing market conditions. 


\subsection{Material and methods used in the analysis of corporate sustainability}

In the analysis of the impact of specific parameters with the application of corporate sustainability, was also used an electronic questionnaire. After a phase of pre-research on a sample of 31 enterprises, the completed questionnaire was transmitted to the manufacturing sector enterprises. The basic enterprise database was using the database of the Statistical Office in 2.793 enterprises, whereby directly were interviewed 2.125 businesses. Overall, we obtained 455 correctly completed questionnaires, which represent a $21.41 \%$ return.

The basic file consists of small, medium and large enterprises in selected industries. Due to the nature of the corporate sustainability concept, we decided to exclude micro-enterprises from the survey. In the area of capital structure, we proceeded without any restriction. In order to apply the results and conclusions to the basic file, we verified the sample in terms of its representativeness. For verification, we used the nonparametric Chi-square test of homogeneity. Two basic characteristics of representativeness we chose size of the business and core competencies, respectively type of industry. The usage of Chi-square test is based on the hypothesis H0, which claims that empirical class frequencies are equal to the theoretical share (classroom frequency) and the hypothesis $\mathrm{H} 1$ that the claim is rejected. For verifying hypotheses at $5 \%$ significance level, the research sample can be considered representative of the company size $(p=0.591)$ as well as the main areas of the company $(\mathrm{p}=0.052)$. The following tables show the output of the statistical program SPSS which was used to verify representativeness of the sample by size of the enterprise and core business (see Tab. 2 and Tab. 3).

Tab. 2 - Verification of representativeness of the survey sample by size of enterprise. Source: own

\begin{tabular}{|l|c|c|c|c|c|}
\hline & $\begin{array}{c}\text { Observed } \\
\text { N }\end{array}$ & $\begin{array}{c}\text { Expected } \\
\text { N }\end{array}$ & Residual & \multicolumn{2}{|c|}{ Test Statistics } \\
\hline $\begin{array}{l}\text { Small } \\
\text { enterprises }\end{array}$ & 287 & 297.3 & -10.3 & Chi-Square & 1.051 \\
\hline $\begin{array}{l}\text { Medium-sized } \\
\text { enterprises }\end{array}$ & 128 & 120.9 & 7.1 & Df & 2 \\
\hline $\begin{array}{l}\text { Large } \\
\text { enterprises }\end{array}$ & 40 & 36.8 & 3.2 & Asymp. Sig. & .591 \\
\hline Total & 455 & \multicolumn{4}{|l}{} \\
\cline { 1 - 5 }
\end{tabular}


Tab. 3 - Verification of representativeness of the sample used by main areas of the company.

Source: own

\begin{tabular}{|l|c|c|c|}
\hline Core of business & Observed & Expected & Residual \\
\hline Mining & 14 & 9.0 & 5.0 \\
\hline Leather industry & 8 & 11.2 & -3.2 \\
\hline Wood-processing and furniture industry & 56 & 60.6 & -4.6 \\
\hline Pulp and paper industry & 20 & 21.8 & -1.8 \\
\hline $\begin{array}{l}\text { Chemical industry, manufacturing of rubber, plastic } \\
\text { production, coke and related products }\end{array}$ & 59 & 60.6 & -1.6 \\
\hline Pharmaceutical industry & 4 & 2.5 & 1.5 \\
\hline Metallurgical industry & 12 & 11.2 & .8 \\
\hline Engineering industry (including automotive) & 202 & 193.2 & 8.8 \\
\hline Electrical engineering & 42 & 46.3 & -4.3 \\
\hline $\begin{array}{l}\text { Manufacturing of other non-metallic mineral } \\
\text { products }\end{array}$ & 19 & 28.8 & -9.8 \\
\hline Other production & 19 & 9.8 & 9.2 \\
\hline Total & 455 & & \\
\hline Test Statistics & & 18.176 & \\
\hline Chi-Square & & 10 & \\
\hline Df & & & \\
\hline Asymp.Sig & \multicolumn{2}{|l|}{} \\
\hline
\end{tabular}

In the analysis, we examined the attitude of enterprises with how to deal with particular dimensions of corporate sustainability. The options led us to create a sequence of potential business direction, i.e. from an occasional direction, through systematic and long-term engagement, to incorporation of dimensions into the business strategy. We set the following hypotheses:

H5: We assumed that there is the existence of a mutual relation between the business size and the intensity of business's involvement in business sustainability.

H6: We assume that there is the existence of a mutual relation between the form of ownership and the intensity of business's involvement in business sustainability.

\section{SELECTED RESEARCH RESULTS AND DISCUSSION}

\subsection{The impact of specific parameters on business performance}

We state that our research did not confirm statistically significant dependence of the performance of enterprises on the business sector in which they operate.

In the analysis of business performance, we were interested in specific parameters affecting the business performance. As mentioned in Part 3, we assumed that performance will affect such parameters as size, location of the company, and the origin of the capital. We must point out that 
in this case, it is not a primary significance as it is the case of studying the effects of time and use of instruments in the enterprise, use of strategic tools in the form of BSC, KPI information system or BI. We believe that an analysis of these specific parameters can yield interesting findings related to performance.

As follows from the results of descriptive statistics, at the sight of the six performance groups, the greatest frequency is represented in the order of the second performance group - the label is group 1 with performance at the level of $0-2 \%$ ROE, where is ranked only 47 companies $(28.66$ $\%$ ) of the total business sample (see Tab. 4).

Tab. 4 - Frequency: sorting parameter ROE. Source: own

\begin{tabular}{|c|c|c|c|c|c|c|c|}
\hline Group (ROE) & $\begin{array}{c}0 \\
\text { (negative) }\end{array}$ & $\begin{array}{c}1 \\
(0-2 \%)\end{array}$ & $\begin{array}{c}2 \\
(2-4 \%) \\
\end{array}$ & $\begin{array}{c}3 \\
(4-7 \%) \\
\end{array}$ & $\begin{array}{c}4 \\
(7-10 \%) \\
\end{array}$ & $\begin{array}{c}5 \\
\text { (over 10\%) }\end{array}$ & Total \\
\hline \multicolumn{8}{|l|}{ All enterprises } \\
\hline $\begin{array}{l}\text { Number of } \\
\text { enterprises }\end{array}$ & 25 & 47 & 35 & 26 & 12 & 19 & 164 \\
\hline Cumulatively & 25 & 72 & 107 & 133 & 145 & 164 & \\
\hline Percentage $(\%)$ & 15.24 & 28.66 & 21.34 & 15.85 & 7.32 & 11.59 & 100.00 \\
\hline $\begin{array}{l}\text { Cumulatively } \\
(\%)\end{array}$ & 15.24 & 43.90 & 65.24 & 81.10 & 88.41 & 100.00 & \\
\hline
\end{tabular}

In this paper, we focus on the statistically significant dependencies ( $\mathrm{p}$-value $>0.05$ ), and for each dependency, we present the results of statistical indicators and pivot tables: the observed frequencies, expected frequencies and residue.

Tab. 5 - Pivot: Localization x Performance - statistics. Source: own

\begin{tabular}{|l|c|c|c|}
\hline Statistics & Chi-square & sv & $\mathrm{p}$ \\
\hline Pearson's chi-square & 31.57994 & $\mathrm{df}=20$ & $\mathrm{p}=.04799$ \\
\cline { 1 - 2 } The M-V chi-square & 26.06009 & $\mathrm{df}=20$ & $\mathrm{p}=.16384$ \\
\hline The contingency coefficient & .4018310 & \multicolumn{2}{|}{} \\
\cline { 1 - 2 } Cramer's V & .2194086 & \multicolumn{2}{|l}{} \\
\cline { 1 - 2 }
\end{tabular}

Tab. 6 - Pivot: Localization x Performance - frequency. Source: own

\begin{tabular}{|l|c|c|c|c|c|c|c|}
\hline Localization & ROE - 0 & ROE - 1 & ROE - 2 & ROE - 3 & ROE - 4 & ROE - 5 & $\begin{array}{c}\text { Row } \\
\text { total }\end{array}$ \\
\hline \multicolumn{7}{|l|}{ Observed frequency } \\
\hline PO & 4 & 1 & 1 & 0 & 0 & 0 & 6 \\
\hline $\begin{array}{l}\text { NR TN TT } \\
\text { ZA }\end{array}$ & 4 & 10 & 9 & 6 & 1 & 1 & 31 \\
\hline KE & 0 & 0 & 0 & 2 & 0 & 0 & 2 \\
\hline BB & 16 & 33 & 23 & 16 & 9 & 15 & 112 \\
\hline
\end{tabular}




\begin{tabular}{|l|c|c|c|c|c|c|c|}
\hline BA & 1 & 3 & 2 & 2 & 2 & 3 & 13 \\
\hline Total & 25 & 47 & 35 & 26 & 12 & 19 & 164 \\
\hline \multicolumn{7}{|l|}{ Expected frequency } \\
\hline PO & 0.915 & 1.720 & 1.280 & 0.951 & 0.4390 & 0.6950 & 6.00 \\
\hline $\begin{array}{l}\text { NR TN TT } \\
\text { ZA }\end{array}$ & 4.726 & 8.884 & 6.616 & 4.915 & 2.2680 & 3.5910 & 31.00 \\
\hline KE & 0.305 & 0.573 & 0.427 & 0.317 & 0.146 & 0.232 & 2.00 \\
\hline BB & 17.073 & 32.098 & 23.902 & 17.756 & 8.195 & 12.976 & 112.00 \\
\hline BA & 1.982 & 3.726 & 2.774 & 2.061 & 0.9512 & 1.506 & 13.00 \\
\hline Total & 25.000 & 47.000 & 35.000 & 26.000 & 12.000 & 19.000 & 164.00 \\
\hline Observed minus expected frequencies (residue) & & & & \\
\hline PO & 3.085 & -0.720 & -0.280 & -0.951 & -0.439 & -0.695 & 0.00 \\
\hline $\begin{array}{l}\text { NR TN TT } \\
\text { ZA }\end{array}$ & -0.726 & 1.116 & 2.384 & 1.085 & -1.268 & -2.591 & 0.00 \\
\hline KE & -0.305 & 0.573 & -0.427 & 1.683 & -0.146 & -0.232 & 0.00 \\
\hline BB & -1.0732 & 0.902 & -0.902 & -1.756 & 0.805 & 2.024 & 0.00 \\
\hline BA & -0.982 & -0.726 & -0.774 & -0.061 & 1.049 & 1.494 & 0.00 \\
\hline Total & 0.000 & 0.000 & 0.000 & 0.000 & 0.000 & 0.000 & 0.00 \\
\hline
\end{tabular}

The results of Tables (5 and 6) show the highest performance (enterprises with ROE in the range of 7-10\%, respectively over $10 \%$ of group 4 and 5) reach businesses established in the region Bratislava, respectively Banská Bystrica. The lowest performance (group 0 and 1; where ROE is negative, respectively 0-2\%) was reached by enterprises in the region Prešov. Due to a lower frequency representation of enterprises in other regions and in terms of relatively equal performance achievement, we included regions Nitra, Trenčín, Trnava and Žilina to the same group. This group is typical that the most businesses achieved 0-4\% ROE.

Tab. 7 - Pivot: Turnover x Performance - statistics. Source: own

\begin{tabular}{|l|c|c|c|}
\hline Statistics & Chi-square & sv & p \\
\hline Pearson's chi-square & 31.34774 & $\mathrm{df}=15$ & $\mathrm{p}=.00789$ \\
\hline M-V chi-square & 33.51585 & $\mathrm{df}=15$ & $\mathrm{p}=.00398$ \\
\hline The contingency coefficient & .4005889 & \multicolumn{2}{|l|}{} \\
\hline Cramer's V & .2524181 & \multicolumn{2}{|l|}{} \\
\hline
\end{tabular}

Tab. 8 - Pivot: Turnover x Performance - frequency. Source: own

\begin{tabular}{|l|c|c|c|c|c|c|c|}
\hline Turnover & $\begin{array}{c}\text { ROE } \\
-0\end{array}$ & $\begin{array}{c}\text { ROE } \\
-1\end{array}$ & $\begin{array}{c}\text { ROE } \\
-2\end{array}$ & $\begin{array}{c}\text { ROE } \\
-3\end{array}$ & $\begin{array}{c}\text { ROE } \\
-4\end{array}$ & $\begin{array}{c}\text { ROE } \\
-5\end{array}$ & $\begin{array}{c}\text { Row } \\
\text { total }\end{array}$ \\
\hline Observed frequency \\
\hline 0-2 mil. $€ /$ year & 13 & 32 & 17 & 9 & 7 & 7 & 85 \\
\hline
\end{tabular}




\begin{tabular}{|c|c|c|c|c|c|c|c|}
\hline 2-10 mil. $€ /$ year & 6 & 10 & 10 & 9 & 0 & 1 & 36 \\
\hline $10-50$ mil. $€ /$ year & 3 & 4 & 4 & 5 & 1 & 4 & 21 \\
\hline over 50 mil. $€ /$ year & 3 & 1 & 4 & 3 & 4 & 7 & 22 \\
\hline Total & 25 & 47 & 35 & 26 & 12 & 19 & 164 \\
\hline \multicolumn{8}{|l|}{ Expected frequency } \\
\hline 0-2 mil. €/year & 12.957 & 24.359 & 18.140 & 13.475 & 6.219 & 9.847 & 85.00 \\
\hline 2-10 mil. €/year & 5.487 & 10.317 & 7.682 & 5.707 & 2.634 & 4.170 & 36.00 \\
\hline $10-50$ mil. $€ /$ year & 3.201 & 6.018 & 4.481 & 3.329 & 1.536 & 2.432 & 21.00 \\
\hline over 50 mil. $€ /$ year & 3.353 & 6.304 & 4.695 & 3.487 & 1.609 & 2.548 & 22.00 \\
\hline Total & 25.000 & 47.000 & 35.000 & 26.000 & 12.000 & 19.000 & 164.00 \\
\hline \multicolumn{8}{|c|}{ Observed minus expected frequencies (residue) } \\
\hline 0-2 mil. €/year & 0.042 & 7.640 & -1.140 & -4.475 & 0.780 & -2.847 & 0.00 \\
\hline 2-10 mil. €/year & 0.512 & -0.317 & 2.317 & 3.292 & -2.634 & -3.170 & 0.00 \\
\hline 10-50 mil. €/year & -0.201 & -2.018 & -0.481 & 1.670 & -0.536 & 1.567 & 0.00 \\
\hline Over 50 mil. $€ /$ year & -0.353 & -5.304 & -0.695 & -0.487 & 2.390 & 4.451 & 0.00 \\
\hline Total & 0.000 & 0.000 & 0.000 & 0.000 & 0.000 & 0.000 & 0.00 \\
\hline
\end{tabular}

The statistically significant dependence in the set of enterprises resulted in relation to turnover and business performance with corrected CC 0.45 . The results clearly show (see Table 7 and 8) that higher turnover has an impact on achieving greater efficiency, and this fact was reflected in all categories. The boundary results show that companies with the highest turnover (over 50 mil. $€$ /year) achieved an excellent performance (group 4 and $5-7-10 \%$ ROE, above $10 \%$ ). The enterprises with the lowest value of turnover to 2 million $€$ /year achieve positive but the lowest ROE $0-2 \%$.

After the examination of parameters, such as localization and turnover of the company, the results show that there is dependence of these parameters on performance of the company expressed through ROE. On the other hand, the dependence of performance has not been confirmed in the case of the enterprise sector, legal form or size of the business. This means that the hypothesis cannot be confirmed.

\subsection{The impact of specific parameters on the corporate sustainability concept}

The corporate sustainability concept essentially consists of economic, social and environmental dimensions. Business attitudes with how to deal with particular dimensions of corporate sustainability may vary. The attention was focused on various options on which we have set up a sequence of possible direction of enterprises - from occasional focusing on areas, through the systematic and long-term dedication to the areas, to including areas in corporate strategy. The aim was to find out how individual companies deal with subject areas in the implementation of their activities. Among all the options, we have chosen only relevant options (see Fig. 3). 


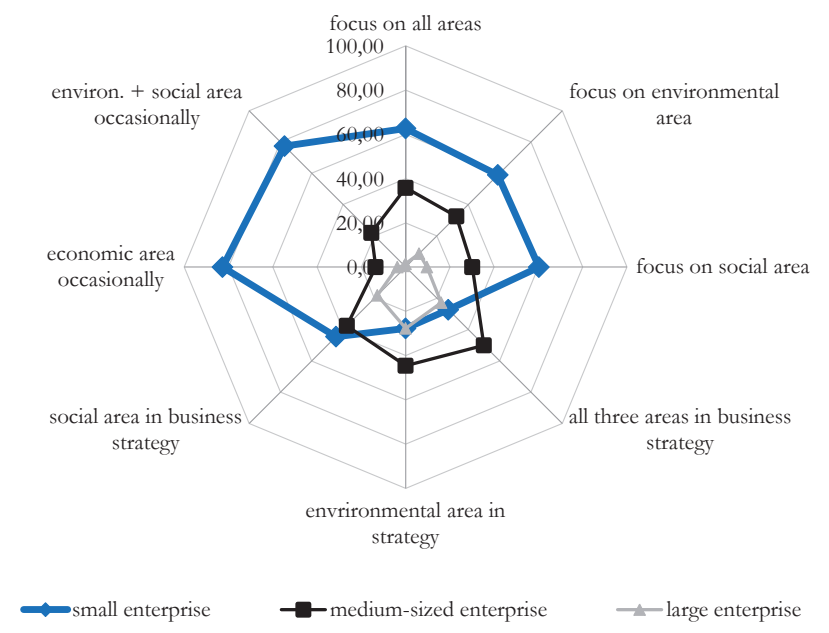

Fig. 3 - The business focus on corporate sustainability concept areas according to the enterprise size. Source: own

Based on the obtained responses, we divided enterprises into the following categories:

The occasional focus on particular areas: in this group, small businesses occasionally focusing on all three areas prevail. Medium-sized enterprises occasionally focus on social and environmental issues in a larger extent. Only 3.70 percent of large enterprises occasionally focus on the economic area.

Businesses primarily focusing on environmental or social areas: from the results, it is evident, that the ratio of the focus on one or the other area is relatively same (151/176). When mutually compared, however, businesses are more engaged in the social area. In all businesses, the environmental area slightly lags behind (the differences are 17 within small businesses and only 4 within medium-sized and large businesses). The result is also similar in respect to the capital structure rate.

The systematic focus on all three areas: based on the results of the research, we included 67 businesses to this group; the majority of them are small businesses with 63 percent share, mediumsized enterprises have 34 percent share and large businesses represent 1.5 percent.

Businesses having the areas incorporated in the strategy: this group contains 44 businesses which, besides that they are involved in all areas, also have them incorporated in the business strategy. As can be seen in Figure 3, half of them are medium-sized businesses (50 \%). The rest is represented by small businesses $(27 \%$ ) and large businesses (almost $23 \%$ ). If we take the size structure of businesses into account, 10 large businesses out of 40 have the areas incorporated in their strategy. The same applies to 22 medium-sized businesses out of 128 and only 12 small businesses out of 287. As expected, larger businesses are more engaged in the strategy than small or medium-sized ones. As for the explicit focus on environmental or social areas in the strategy, the social area is prevailing in small businesses, in medium-sized and large enterprises the environmental area dominates. 
In the analysis, we focused on the correlation of corporate sustainability in relation to variables such as company size and form of ownership of the company. We investigated whether these variables have an effect on what intensity the company is dealing with the concept. On this basis, we defined the hypothesis, where we assume that there is a correlation between how the company deals with the corporate sustainability issues and enterprise size. It means that the intensity of how the business is concerned with the areas (economic, environmental, and social) depends on the size company. To verify the hypothesis, we used the nonparametric Spearman's rank correlation coefficient (see Tab. 9).

Tab. 9 - The relationship between the corporate sustainability concept and size of business. Source: own

\begin{tabular}{|c|c|c|c|c|}
\hline & & & Size & $\mathrm{H} 5$ \\
\hline \multirow{6}{*}{$\begin{array}{l}\text { Spearman's } \\
\text { rho }\end{array}$} & \multirow{3}{*}{ Size } & Correlation Coefficient & 1,000 & ,373 \\
\hline & & Sig. (2-tailed) & . &, 000 \\
\hline & & $\mathrm{N}$ & 455 & 455 \\
\hline & \multirow{3}{*}{ H5 } & Correlation Coefficient & ,373 & 1,000 \\
\hline & & Sig. (2-tailed) & ,000 & . \\
\hline & & $\mathrm{N}$ & 455 & 455 \\
\hline
\end{tabular}

From the results, it is evident that there is a moderate dependence between the given variables ( $\mathrm{p}$-value $=0$, Spearman's rank coefficient $=0.373)$, whereby the strongest dependence is currently on environmental opportunities. This implies that the larger the enterprise is, the greater the focus on environmental issues and social opportunities is. Based on this fact, this hypothesis could be confirmed.

In our research, we also focused on the capital structure of company. In the hypothesis H6, we examine the assumption of the existence of dependency between how the company deals with sustainability and capital structure of the company. To verify this assumption, we used the Chisquare test of independence. We found that investigated characters are not independent ( $\mathrm{p}$-value =0). To determine the power, we used the correlation coefficient Cramer ś V (see Tab. 10 and 11).

Tab. 10 - Analysis of the corporate sustainability and capital structure. Source: own

\begin{tabular}{|l|c|c|c|}
\hline & Value & Df & Asymp. Sig. (2-sided) \\
\hline Pearson's Chi-Square & 53,699 & 24 &, 000 \\
\hline Likelihood Ratio & 57,059 & 24 &, 000 \\
\hline Linear-by-Linear Association & 24,027 & 1 &, 000 \\
\hline N of Valid Cases & 455 & & \\
\hline
\end{tabular}


Tab. 11 - Analysis of the corporate sustainability and capital structure. Source: own

\begin{tabular}{|l|c|c|}
\hline Nominal by Nominal & Value & Approx. Sig. \\
\hline Phi &, 344 &, 000 \\
\hline Cramer's V &, 243 &, 000 \\
\hline N of Valid Cases & 455 & \\
\hline
\end{tabular}

The results show that between the research variables there is moderate dependence. This means, as in the previous case, that application of the corporate sustainability concept also affects the capital structure $(\mathrm{CV}=0.243)$ so the hypothesis $\mathrm{H} 6$ could be confirmed.

\section{CONCLUSION}

The strategic performance management as well as the corporate sustainability concept is gradually coming into the center of attention of Slovak enterprises. The paper is a synthesis of researches conducted on a sample of enterprises in the area of business performance and corporate sustainability. From several studies carried out in the management and measurement performance issue, it is evident that performance is affected by many factors. These factors are important for improving business performance. In the present paper, we focus on other specific factors, which may also affect the performance. For the specific parameters, we consider business location, the turnover, the legal form and so on. The results show that the business location and turnover affect the performance measuring by ROE. On the other hand, the dependence of performance has not been confirmed in the enterprise sector, legal form or size of business. In the field of further research (analyze of turnover and ROE), it would be useful to monitor ROE not only in categories but also in concrete values with the possibility of applying correlation analysis.

In connection with corporate sustainability concept, we focused on the enterprises orientation on particular dimensions as well as parameters such as company size, capital structure of its application. In both examined cases, hence the size of the business and capital structure has a moderate impact on the actual application of the corporate sustainability concept. Also, these parameters are important with the application of corporate sustainability. In further research, it would be useful to focus on exploring other specific indicators (legal form, location and so on) as well as the relationship with corporate sustainability concept and business performance in the form of ROE.

\section{Acknowledgements}

This paper is the partial result of the Ministry of Education of Slovak Republic grant project VEGA Nr. 1/0537/16 - Methods and models of Strategic Business Performance Management and their comparison in companies and multinational corporations.

\section{References}

1. Afonina, A. (2015). Strategic Management Tools and Techniques and Organizational Performance: Findings from the Czech Republic. Journal of Competitiveness, 7 (3), 19-36.

2. Baumgartner, R. J. \& Ebner, D. (2010). Corporate Sustainability Strategies: Sustainability Profiles and Maturity Levels. Sustainable Development, 18 (2), 76-89. DOI: 10.10002/sd447 
3. Bento A., Bento, R. \& White, L. F. (2014). Strategic Performance Management Systems: Impact on business results. Journal of Computer Information Systems, 54 (3), 25-33.

4. Bisbe, J. \& Malagueňo, R. (2012). Using strategic performance measurement systems for strategy formulation: Does it work in dynamic environments? Management Accounting Research, 23 (4), 296-311. DOI: 10.1016/j.mar.2012.05.002

5. Bourne, M., Neely, A., Mills, J. \& Platts, K. (2003). Implementing performance measurement systems: a literature review. International Journal of Business Performance Management, 5 (5), 1-24. DOI: 10.1504/IJBPM.2003.002097

6. Daum, J. H. (2005). French Tableau de Bord: Better than the Balanced Scorecard? Der Controlling Berater, 7 (2), 459-502.

7. Davis, S. \& Albright, T. (2004). An investigation of the effect of Balanced Scorecard implementation on financial performance. Management Accounting Research, 15, 135-153. DOI: 10.1016/j.mar.2003.11.001

8. De Geuser, F, Mooraj S. \& Oyon, D. (2009). Does the Balanced Scorecard Add Value? Empirical Evidence on its Effect on Performance. European Accounting Review, 18 (1), 93-122. DOI: $10.1080 / 09638180802481698$

9. Financial Times Lexicon. Retrieved from: http://lexicon.ft.com/Term?term=businesssustainability.

10. Fülöp, G. \& Hernádi, B. H (2014). Sustainability Accounting: a Success Factor in Corporate Sustainability Strategy. International Journal of Economics and Management Engineering. 4 (1), 1-21. Retrieved from: http://search.proquest.com/openview/ 92d4e89c798d64f33d3c39196ff9cd0d/1?pq-origsite=gscholar.

11. Gimbert, X., Bisbe, J. \& Mendoza, X. (2010). Measurement Systems in Strategy Formulation Processes. Long Range Planning, 43 (4), 477-497. DOI: 10.1016/j.lrp.2010.01.001

12. Grayson, D., Lemon, M., Slaughter, S., Rodriquez, M. A., Jin, Z., \& Tay, S. (2008). A new mindset for corporate sustainability. Retrieved from: http://www.cisco.com/cisco/web/UK/ pdfs/A_mind_set_for_corporate_sustainability.pdf

13. Heurich, M. \& Vignali, C. (2015). Innovations and its Impact on the Performance of Acute Care Hospitals in Germany - An Investigation Containing Empirical Research and Software Development. Economics and Sociology, 8 (4), 149-164. Doi: 10.14254/2071789X.2015/8-4/11

14. Hudymáčová, M. \& Hila, M. Výkonnost’ podniku. Časopis o jakosti, Katedra kontroly a řízení jakosti, FMMI, VŠB-TU Ostrava. Retrieved from: http://katedry.fmmi.vsb.cz/639/ qmag/mj99-cz.pdf

15. Hubbard, G. (2009). Measuring organizational performance: beyond the triple bottom line. Business Strategy and the Environment, 18 (3), 177-191. DOI: 10.1002/bse.564

16. Hyršlová, J. (2009). Učetnictví trvalo udržitelného roquoje podniku. Praha : Vysoká škola ekonomie a managementu, 2009, 174 s. Retrieved from: http://www.enviweb.cz/download/ea/ ucetnictvi_udrzitelneho_rozvoje.pdf

17. Chenhall, R. H. (2005). Integrative strategic performance measurement systems, strategic alignment of manufacturing, learning and strategic outcomes: an exploratory study. Accounting, Organizations and Society, 30 (5), 395-422. DOI: 10.1016/j.aos.2004.08.001 
18. Ionescu-Somers, A. (2012). What's stopping your sustainability schemes? You are. Switzerland: International Institute for Management Development. Retrieved from: http://www.imd. org/research/challenges/upload/TC023-12_What-s-stopping-your-sustainability-schemes. pdf

19. Miron, D. \& Petrache, A. M. (2012). The Linkage between Corporate Social Performance and the Corporate Financial Performance in the Information and Communication Technology Multinational Companies of Romania. Economics \& Sociology, 5 (2a), 86-99.

20. Pinheiro de Lima, E., Gouvea da Costa, S. E. \& Angelis, J. J. (2009). Strategic performance measurement systems: a discussion about their roles. Measuring Business Excellence, 13 (3), 39 48. DOI: $10.1108 / 13683040910984310$

21. Porrit, J. (2003). The World in Context: Beyond the Business. Case for Sustainable Development. University of Cambridge. Retrieved from: http://www.cpsl.cam.ac.uk/Test/WhatisSustai nabilityLeadership/ /media/Files/Complete $\% 20$ publications $\% 20$ for $\% 20$ download/The_ World_in_Context.ashx

22. Rajnoha, R. et al. (2013). Meranie a riadenie výkonnosti podnikov. 1th edition Zvolen: Vydavatel'stvo Technickej univerzity vo Zvolene

23. Rajnoha, R., Štefko, R., Merková, M. \& Dobrovič, J. (2016). Business Intelligence as a Key Information and Knowledge Tool for Strategic Business Performance. Economics and Management, 19 (1), 183-203. DOI: 10.15240/tul/001/2016-1-013

24. Rigby, D., \& Bilodeau, B. (2015). Management Tools and Trends 2015. Boston: Bain \& Company. Retrieved from: http://www.bain.com/publications/articles/management-toolsand-trends-2015.aspx

25. Setthasakko, W. (2007). Determinants of corporate sustainability: Thai frozen seafood processors. Bangkok: Thammasat University. British Food Journal, 109 (2), http://dx.doi. org/10.1108/00070700710725518

26. Shirastava, P., \& Hart, S. (1995). Creating Sustainable Corporations. Business Strategy and the Environment, 4 (3), 154-165, DOI: 10.1002/bse.3280040307

27. Stead, J. G., \& Stead, W. E. (2012). Manažment pre malú planétu. Prečo je dôležité menit'stratégie neobmedzeného rastu na stratégie udržatel’nosti. Bratislava: Eastone Books.

28. Striteska, M., \& Spickova, M. (2012). Review and Comparison of Performance Measurement Systems. Journal of Organizational Management Studies, 20 (12). DOI: $10.5171 / 2012.114900$

29. Székely, F., \& Knirsch, M. (2005). Leadership and Corporate Responsibility. Metrics for Sustainable Corporate Performance. Berlin: European School of Management and Technology. Retrieved from: http://www.esmt.org/.../Working\%20Paper_Metrics.pdf

30. Wilson, M. (2003). Corporate sustainability: What is it and where does it come from? Ivey Business Journal. Retrieved from: http://iveybusinessjournal.com/topics/socialresponsibility/corporate-sustainability-what-is-it-and-where-does-it-come-from\#. UsqSB9h3vIU 
31. Zelený, J. (2007). Orientácia v oblasti systémového inžinierstva. Základ úspešného environmentálneho inžiniera. Ekológia a environmentalistika: medżinárodná vedecká konferencia k. 15. výročiu založenia Fakulty ekológie a environmentalistiky TU vo Zvolene, s. 253-264. Retrieved from: http://www.tuzvo.sk/files/FEE/dekanat_fee/3b_ZelenyII_AFE.pdf

\section{Contact information}

Assoc. Prof. Rastislav Rajnoha, PhD.

Tomas Bata University in Zlin, Faculty of Management and Economics

Nám. T. G. Masaryka 5555, 76001 Zlín, Czech Republic

E-mail:rajnoha@fame.utb.cr.

Ing. Petra Lesniková, PhD.

Technical University in Zvolen, Faculty of Wood Sciences and Technology

Ul. T. G. Masaryka 2117/24, 96053 Zvolen, Slovak Republic

E-mail:lesnikova@tuzvo.sk 